\section{YEARBOOK}

of ANTITRUST

and REGULATORY

STUDIES

www.yars.wz.uw.edu.pl
Peer-reviewed scientific periodical, focusing on legal and economics issues of antitrust and regulation.

Creative Commons Attribution-No Derivative Works 3.0 Poland License

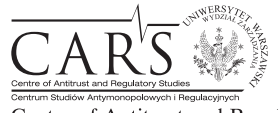

Centre of Antitrust and Regulatory Studies, University of Warsaw, Faculty of Management www.wz.uw.edu.pl

\title{
Commitment Decisions under the Polish Competition Act - Enforcement Practice and Future Perspectives
}

\author{
by \\ Tomasz Kozieł*
}

\section{CONTENTS}

I. Preliminary remarks

II. Commitment decisions under Polish law

1. The underlying idea

2. Legal background

3. Procedural aspects

4. Consequences of a failure to comply with commitments

III. Commitment decisions and optimal enforcement of competition law

1. Commitments and deterrence

2. Improving legal certainty

3. Restorative justice

IV. Conclusion

\section{Abstract}

The aim of this paper is to provide an analysis of the commitments procedure under the Polish competition law, including both legal and economic perspective. The outcome of this research is supposed to help in estimation whether novel negotiated instruments may be successfully employed in the field of antitrust enforcement. Hence, the paper first introduces the legal background of the commitments decisions, with focus on the specific features of the procedure. Being a tool of antitrust enforcement, commitment decisions should contribute to its goals. Therefore, the paper identifies such objectives drawing on the economic literature. It is in the light of these criteria that the decision practice of the Polish competition authority, still in the stage of development, is subsequently evaluated. This assessment reveals

* Tomasz Kozieł LL.M., Allerhand Institute (IA) Research Associate, practitioner in competition law in Brussels. 
circumstances, under which the competition authority is particularly apt to engage into commitments procedure. It allows also for a conclusion that the application of this negotiated instrument is in principle commensurate with the exigencies following from economic theory. Nevertheless, where necessary, the paper provides suggestions as to the improvement of application of commitment decisions.

\section{Résumé}

Le but de cet article est de présenter une analyse de la procédure d'engagements en droit polonais de la concurrence, d'un point de vue juridique et économique. Le résultat de cette recherche permettra d'estimer l'efficacité de ces nouvelles procédures négociées dans le domaine du droit de la concurrence. Ainsi, l'article introduit le cadre juridique de la procédured'engagements en Pologne, en se focalisant sur les éléments spécifiques d'un tel mécanisme. Instrument de mise en œuvre du droit de la concurrence, la procédure d'engagements devrait contribuer à accomplir les buts de cette politique. Par conséquent, l'article essaie d'identifier de tels objectifs, en s'appuyant sur la littérature économique. La pratique décisionnelle de l'autorité de la concurrence polonaise est par la suite analysée à la lumière de ces critères, tout en gardant à l'esprit qu'elle n'en est qu'à ses prémisses. Cette analyse revèle les circonstances dans lesquelles l'autorité de la concurrence est particulièrement susceptible de mettre en œuvre une procédure d'engagements. Elle nous permet aussi de constater que l'application des procédures négociées en Pologne est, en principe, conforme aux exigences relevant de la théorie économique. Néanmoins, quelques suggestions visant à l'amélioration de la procédure d'engagements sont proposées, au cas où cela soit nécessaire.

Classifications and key words: commitment decision; enforcement of competition law; legal certainty; restorative justice.

\section{Preliminary remarks}

Optimal antitrust enforcement is just as important in the area of competition policy as correct formulation of legal rules. Legal compliance can be achieved only by the use of enforcement mechanisms that align individual incentives with social objectives through the alleviation of the moral hazard of potential violators ${ }^{1}$. A degree of compliance can be determined by several factors, all of which must be considered within the enforcement process. Most commentators

1 G.J. Stigler, 'The Optimum Enforcement of Laws' (1970) 78(3) Journal of Political Economy 526 et seq; I.R. Segal, M.D. Whinston, 'Public vs. Private Enforcement of Antitrust Rules: A Survey', Stanford Law School Working Paper No. 335, p. 3. 
agree that antitrust enforcement should above all prevent undertakings from violating competition rules ${ }^{2}$. To achieve this, the cost of an infringement need to increase making competition law violations unprofitable. However, deterrence is not in itself sufficient to ensure a high level of law compliance which is also dependent on the clarity of the content of the applicable legal rules. Hence, it is vital that enforcement increases legal certainty especially in the field of competition law that needs to respond swiftly to dynamic market changes ${ }^{3}$. Moreover, in cases where an infringement has already occurred, the appropriate enforcement agency needs to decide how to deal with its consequences. Literature notes in this context that finding a workable solutions to the problem at hand and restoring effective competition on a given market is much more important than actually punishing the offender ${ }^{4}$. It is in the light of such criteria that the effectiveness of particular antitrust enforcement tools should be assessed.

An infringement decision, often accompanied by a fine, is a legal instrument traditionally employed in the enforcement of behavioural competition law in Poland ${ }^{5}$. It establishes a breach of competition law (subject to judicial review) and thus sends a clear message to other market participants as to what behaviour is illegal in Polish antitrust. Moreover, since the amount of the fine reflects the profits gained by the infringer from the violation ${ }^{6}$, it implements the deterrence theory? ' 'Restorative justice' is achieved mainly by prohibiting

2 G. Spagnolo, 'Leniency and Whistleblowers in Antitrust' [in:] P. Buccirossi (ed.), Handbook of antitrust economics, MIT Press, Cambridge, 2008, p. 256.

3 W. Wils, 'Optimal Antitrust Fines: Theory and Practice' (2006) 29(2) World Competition 185 .

4 S. Wilks, 'A Political Science Approach: Restorative justice and the fairness critique' [in:] C.-D. Ehlermann, M. Marquis (eds.), European Competition Law Annual 2008: Antitrust Settlements and EC Competition Law, Hart, Oxford, 2010, p. 93-110.

5 Article 10 in connection with Article 106 of the Act on Competition and Consumer Protection of 16 February 2007 (Journal of Laws 2007 No. 50, item 331, as amended, hereafter, the Competition Act). The English version is available at http://www.uokik.gov.pl/download. php?plik $=7618$.

6 UOKiK, 'Wyjaśnienia w sprawie kryteriów wyznaczania wysokości kar pieniężnych nakładanych na przedsiębiorców naruszających prawo antymonopolowe' ['Explanations on the criteria for setting the amount of fines imposed on undertakings infringing antitrust law'], para 2.2, Polish version available at: http://www.uokik.gov.pl/ download.php?plik=1217. On the fines imposed in Poland for violations of competition law see more specifically M. BogomilskaKról, 'Kary pieniężne - główne kierunki ewolucji w okresie 20 lat rozwoju polskiego prawa antymonopolowego' (2010) 5 Europejski Przeglad Sadowy 5-14.

7 W. Wils, 'Optimal Antitrust Fines...', p. 191. Ideally this amount should be multiplied by the inverse probability of detection. E. Combe, 'À la recherché de la sanction optimale' (2006) 4 Concurrences 12. 
the undertaking in question from the use of the contested practice in the future. Such ban constitutes an integral part of an infringement decision ${ }^{8}$.

Nonetheless, traditional enforcement of competition law has a major disadvantage - it is rather costly ${ }^{9}$. Many legislators decided therefore to employ various negotiated enforcement instruments that make it possible for antitrust authorities to re-allocate their limited resources and increase their performance efficiency. Two such instruments were introduced into the Polish antitrust procedure: the leniency programme and commitment decisions. It is particularly interesting to see how the latter relates to the objectives of antitrust enforcement and what advantages can it bring for both the undertakings and the authority. This paper will analyse the legal background and principles underpinning commitment decisions under Polish competition law from this very angle. The practical reflection of these principles in the administrative practice of the UOKiK will also be noted. In that respect, comments will be made concerning possible improvements of the effectiveness of the commitments procedure. The purpose of this paper is thus to introduce the readers to the specific features of the Polish commitments procedure and to evaluate the practice of its application.

\section{Commitment decisions under Polish law}

\section{The underlying idea}

Commitment decisions are a reflection of the plea bargaining model. It allows litigation parties (for instance a prosecutor and a defendant) to enter into a bargain with the other side of the proceedings. Such a bargain is overall more beneficial for both parties than the estimated outcome of a trail, saving litigation costs and facilitating the arrival at a more socially desirable solution ${ }^{10}$. In consequence, the defendant is handed down a lesser than expected sentence without prejudice however to social welfare ${ }^{11}$. This trade-off between justice and procedural efficiency allows an enforcement agency, such as a competition

8 Article 10 of the Competition Act.

${ }^{9}$ Detection of infringements, especially cartels, is particularly difficult in the area of competition law due to great information asymmetry. See on that D. Besanko, D.F. Spulber, 'Antitrust Enforcement under Asymmetric Information' (1989) 99(396) The Economic Journal 408.

10 See R. Adelstein, T.J. Miceli, 'Toward a Comparative Economics of Plea Bargaining' (2001) 11(1) European Journal of Law and Economics 50; G.M. Grossman, M.L. Katz, 'Plea Bargaining and Social Welfare' (1983) 73(4) The American Economic Review 749-757.

11 R. Adelstein, T.J. Miceli, 'Toward a Comparative Economics...'. 
authority, to invest the time and resources normally spent on prosecution in the detection of other infringements.

Efficiency considerations concerning antitrust proceedings were also at the heart of the Polish legislator when commitment decisions were introduced into UOKiK's toolkit in 2004. It was believed that accepting commitments from undertakings may in some cases be a more efficient way to restore effective competition than the imposition of a fine ${ }^{12}$. On the other hand, undertakings would benefit greatly from the inapplicability of Articles 10, 11 and 106 of the Competition Act, which entitle the UOKiK President to issue an infringement decision and impose a fine of up to $10 \%$ of the turnover achieved by the offender in the preceding year. Moreover, since commitments are proposed by the scrutinised undertakings themselves, they can take account of their own interests while formulating potential solutions to an established competition problem $^{13}$.

\section{Legal background}

Commitment decisions were introduced into Polish competition law on the day of its EU accession with the entry into force of a modernization package concerning the Competition Act of $2000^{14}$. However, it would be incorrect to state that no form of settlement was available in Polish behavioural competition law before that moment. The aforementioned amendment repealed Article 89 of the Competition Act of 2000, which used to allow the UOKiK President to not levy a fine in cases of minor violations if an undertaking admitted to anticompetitive practice. In such cases, an infringement decision was issued prohibiting the exercise of the contested practice without however having to prove its adverse effect on competition. Although this mechanism constituted a form of a 'settled solution'15, it left the decision on the remedies to UOKiK. The amendment shifted the initiative in that respect to the undertakings

12 Projekt ustawy o zmianie ustawy o ochronie konkurencji i konsumentów oraz o zmianie niektórych innych ustaw [Proposal for an amendment of the competition and consumer protection act and several other acts] of 20 February 2004 (Druk Sejmowy Nr 2561), para III.4 of the explanatory memorandum attached to the proposal.

13 According to Z. Kmieciak, this is the major advantage of applying negotiated instruments in the field of administrative law: Z. Kmieciak, Mediacja $i$ koncyliacja w prawie administracyjnym, Kraków 2004, p. 18 and 23.

14 Article 11a of the Act on Competition and Consumer Protection of 15 December 2000 (Journal of Laws 2000 No. 122, item 1319), as amended by the modification Act of 16 April 2004 (Journal of Laws 2004 No. 93, item 891).

15 E. Modzelewska-Wąchal, Ustawa o ochronie konkurencji i konsumentów. Komentarz, Warszawa 2002, p. 298. 
themselves following the model of Article 9 Regulation 1/2003 ${ }^{16}$. Indeed, even the travaux préparatoires admitted that the new procedure was analogous to the commitment decisions used in Community competition law enforcement ${ }^{17}$.

Nevertheless, even if the reform was meant to align Polish competition law with the standards of the modernized EU antitrust rules ${ }^{18}$, introducing a domestic commitment procedure was not necessary in order for Poland to participate in the European Competition Network ${ }^{19}$. Despite this fact, the approach adopted by the Polish legislator should be welcomed because it made it possible to avoid procedural discrepancies in cases where both Polish and EU antitrust rules were applicable ${ }^{20}$. In consequence, it assured similar enforcement possibilities irrespective of whether a case is pending before the Commission or the Polish authority. However, Article 12 of the current Competition Act does not implement the European Modernization Regulation nor does it expressly refer to its wording. As a result, its content and the principles of its interpretation remain completely autonomous ${ }^{21}$. These have been developed in the administrative practice of UOKiK and the jurisprudence of Polish courts. They may thus be different from the way Article 9 Regulation 1/2003 is applied by the European Commission. The implications of these particularities can be well demonstrated on the example of the procedure for the adoption of a commitment decision by the Polish competition authority.

\section{Procedural aspects}

According to Article 12 of the 2007 Competition Act, the UOKiK President can impose an obligation upon an entrepreneur to exercise specified commitments at any time of the proceedings provided a violation of Polish or EU competition rules has been rendered plausible and the company in

16 Council Regulation of 16 December 2002 No. 1/2003 on the implementation of the rules on competition laid down in Articles 81 and 82 of the Treaty, OJ [2003] L 1/1.

17 Projekt ustawy..., para III.4

18 Ibidem, para. I.

19 A. Gill, M. Swora, 'Decyzja zobowiązująca jako metoda rozwiązywania sporów w postępowaniu przed Prezesem Urzędu Ochrony Konkurencji i Konsumentów’ (2005) 3 Kwartalnik Prawa Publicznego 107.

${ }^{20}$ For instance, the first commitments decision under both Polish and EU competition law provisions prohibiting abuse of dominant position concerned unilateral practices engaged into by the authors' association ZAiKS. Decision of the UOKiK President of 24 August 2010, DOK-7/2010.

21 This is confirmed by the structure of the explanatory memorandum, which groups new provisions in three separate sections, first of which refers to the necessity to align Polish provisions with the EU competition law and the remaining two concern the improvement of the effectiveness of Polish antitrust law. 
question has agreed to take or discontinue certain actions in order to prevent the infringement ${ }^{22}$. The procedure resembles therefore Article 9 Regulation $1 / 2003$ in that a formal decision must be issued making the commitments binding upon its addressees. A commitment procedure is an ordinary antirust proceeding under the Competition Act. Formally speaking, the decision does not constitute any form of settlement but rather, an act where the authority avails itself of the state powers vested in it and unilaterally defines obligations or rights of an individual ${ }^{23}$. It should thus be differentiated from an administrative settlement foreseen by the Polish code of administrative procedure (KPA) ${ }^{24}$ that has been used in domestic antitrust proceedings on several occasions in the past ${ }^{25}$. What makes commitment decisions a 'negotiated instrument' though is the fact that a party to the proceedings may propose the content of the commitments which may, or indeed may not, be accepted by UOKiK.

Despite the ambiguity of the wording of Article $12^{26}$, there should be no doubt that the initiative in proposing commitments lies in the hands of undertakings ${ }^{27}$. This seems to be confirmed by the application practice of Article 12 by UOKiK that awaits a reaction from the scrutinised undertaking to the notification that antitrust proceedings were initiated against it ${ }^{28}$. In that regard, nothing should prevent the authority from indicating to the investigated company that the case may be solved by committing to refrain from adopting certain actions. However, the voluntary nature of commitments requires that the choice of measures should be left entirely up to the undertaking to avoid too much public influence. Thus, the competition authority can make suggestions as to possible modifications of the commitments offered only after they were submitted, if the initial proposal was unsatisfactory ${ }^{29}$.

22 Article 12(3) of the Competition Act.

23 Cz. Martysz, [in:] G. Łaszczyca, Cz. Martysz, A. Matan, Postępowanie administracujne ogólne, Warszawa 2003, p. 650.

24 Article 114 and following of the Code of Administrative Procedure of 14 June 1960 (Journal of Laws 1960 No. 30, item 168, as amended).

25 The purpose of an administrative settlement lies in an arrangement between parties to a proceeding before a public authority rather than between the parties and the authorityy itself. A. Szpor, 'Mediacja w prawie konkurencji. Prezes UOKiK jako mediator publiczny w sprawach praktyk ograniczających konkurencję' [in:] H. Michnińska, Mediacja w sprawach administracyjnych, Warszawa 2007, p. 90; A. Gill, M. Swora, 'Decyzja zobowiązująca...', p. 123.

26 This ambiguity and in particular the lack of specific procedural rules was pointed out by A. Gill, M. Swora, 'Decyzja zobowiązująca...', p. 125.

27 See K. Kohutek, [in:] K. Kohutek, M. Sieradzka, Ustawa o ochronie konkurencji i konsumentów. Komentarz, Warszawa 2008, p. 434.

28 Decisions of the UOKiK President of June 4 2009, NR-7/2009 and of 21 July 2008, RBG-17/2008.

${ }^{29}$ K. Kohutek, [in:] K. Kohutek, M. Sieradzka, Ustawa ..., p. 436. 
Furthermore, only after has an undertaking been officially notified about the fact that antitrust proceedings were initiated against it can commitments be first proposed. This follows inter alia from the requirement that the UOKiK President can accept an offer only if a violation 'has been rendered plausible' - a well-established standard of Polish administrative law and jurisprudence ${ }^{30}$. The commitments procedure under Regulation 1/2003 is therefore less specific than the Polish requirement whereby an infringement does not have to be proven with certainty, its existence must nevertheless be seen as probable or credible. One can speak of rendering a violation of competition rules plausible if UOKiK considers it to be obviously more probable than any other alternative solution to the practice in question ${ }^{31}$. Thus, an in-depth analysis of the circumstances of the case is not necessary because the authority's conviction about the existence of a violation, inferred from the data collected or submitted by third parties, suffices to fulfil this standard. It is argued that initiating an antitrust procedure renders by itself the infringement plausible since the authority would not have proceeded otherwise into the formal stage of investigation ${ }^{32}$. For that reason, the content of a commitment decision does not have to reflect the expected infringement decision. For instance, a relevant market established in a commitment decision may somewhat differ from what would have been established under an adversarial procedure requiring full evidentiary backing ${ }^{33}$. Likewise, the authority may base its opinion in a commitment procedure on information gathered from a small fraction of the parties affected by the practice ${ }^{34}$. However, should there be different elements constituting jointly an infringement of competition law, UOKiK must render the existence of each of them plausible ${ }^{35}$. The adoption of a standard that is well-established in domestic jurisprudence is applauded; it makes it possible to avoid unnecessary controversies about the extent to which an infringement has to be demonstrated. It also facilitates the adoption of a benchmark for the assessment of the adequacy and proportionality of the accepted commitments ${ }^{36}$.

30 Judgment of the Polish Supreme Administrative Court of 5 May 1995, SA/Wr 2223/94 (Lex No. 26854), referred to in the UOKiK decision of 4 July 2008, DOK-3/2008. See also the UOKiK decision of 24 August 2006, RBG-12/2006.

31 A. Gill, M. Swora, 'Decyzja zobowiązująca...', p. 128.

32 C. Banasiński, E. Piontek (eds.), Ustawa o ochronie konkurencji i konsumentów. Komentarz, Warszawa 2009, p. 311.

33 Decision DOK-3/2008, (at 16).

34 Decision of the UOKiK President of 12 February 2010, DOK-1/2010.

35 Decisions of the UOKiK President of 11 June 2008, RWR-24/2008 and of 28 August 2008, RWA-27/2007.

36 This was one of the main controversies that the EU Court of Justice had to deal with in its recent judgment of 29 June 2010 in the Alrosa case. See case C-441/07 Commission v Alrosa, not yet reported. 


\section{Consequences of a failure to comply with the commitments}

Sanctions for the failure to comply with the content of commitment decisions constitute an important aspect of their enforcement. Unlike the provisions of Regulation $1 / 2003^{37}$, the UOKiK President cannot impose in a commitments decision a fine analogous to that normally accompanying an infringement decision. To do so, the authority would have to re-open the proceedings and rule on the subject matter of the case after collecting compelling evidence.

In the Polish commitment procedure, fines can only be imposed for a delay in compliance (up to EUR 10000 per day ${ }^{38}$ ) or for the failure to provide UOKiK with information on the compliance with its content (up to EUR $50000000^{39}$ ). Although the authority cannot immediately react to a breach of binding commitments, the approach adopted here seems to be appropriate since a fine of up to $10 \%$ of the scrutinised company's yearly turnover is imposed only if an infringement has been proven. Moreover, imposing such fine for a breach of commitments, accepted by virtue of the discretionary powers of the authority, would be doubtful from the point of view of legal protection $^{40}$. If a fine is imposed, an undertaking should be allowed to contest fully the fact that an infringement was establishment, whilst that is not the case in the commitments procedure ${ }^{41}$. Furthermore, issuing a formal infringement decision is important with respect to other legal consequences that can be drawn from the violation of antitrust rules such as contract nullity and followon claims ${ }^{42}$. In order to persuade the offender to comply with the commitments, the authority can impose the aforementioned periodic penalty payments as well as a fine for the failure to provide the required data. The solution adopted

37 See Article 23(2)(c) Regulation 1/2003.

38 Article 107 of the Competition Act.

39 Article 106(2)(2) of the Competition Act.

${ }^{40}$ For instance, the argument that the Commission may impose a fine for the breach of commitments equal to that which would have been imposed under the adversarial procedure was used by the claimants in Alrosa to support the view that the discretionary powers of the Commission in the commitments procedure should be limited. Supra note 36.

${ }^{41}$ In numerous cases commitments are offered immediately after an undertaking is notified about the fact that proceedings were initiated against it (Decisions RWA-27/2007 and DOK$3 / 2008$ ) even though on occasion, the undertaken comportment is adopted even prior to that (Decision of the UOKiK President of 13 September 2007, RWA-30/2007). The fact of the infringement is thus neither contested nor discussed.

42 Although these can also be established independently by a civil court. See A. JurkowskaGomułka, 'W stronę umocnienia prywatnoprawnego wdrażania zakazów praktyk ograniczających konkurencję - glosa do uchwały SN z 23.0.2008 r. (III CZP 52/08)' (2010) 5 Europejski Przeglad Sadowy 46 et seq. 
in the Polish Competition Act seems both effective and coherent with the system of antitrust enforcement.

\section{Commitment decisions and optimal enforcement of competition law}

\section{Commitments and deterrence}

In order to achieve optimal law enforcement, it is necessary to properly employ the available enforcement tools. The instrument used has to respond to the needs of the situation without incurring unnecessary costs to the society as well as the offender. Due to the great variety of infringement types (differing in their gravity, aim and mode of operation), an enforcement agency has to be able to make use of various instruments. This need was addressed by the Polish legislator with the introduction of commitment decisions into Polish antitrust procedure in 2004. Its aim was to better target those forms of violations where the issuance of a formal infringement decision under the adversarial procedure was not necessary ${ }^{43}$. The following part of this article will analyse under what conditions should commitment decisions be adopted and whether this standard is satisfied by UOKiK's decisional practice. This assessment will be based on the typology of roles that law enforcement, competition law in particular, has to fulfil, mentioned in the introduction to the article ${ }^{44}$.

Optimal deterrence is crucial in the enforcement of competition law in order to preserve vital competition. Serious infringements should be punished with adequate sanctions otherwise there is no credible threat of prosecution, failing in turn to prevent undertakings from further violations (under-deterrence). Fines have to be sufficiently high in comparison to the illegal gains associated with antitrust violations to stop anticompetitive behaviours ${ }^{45}$. On the other hand, the imposition of excessive sanctions on those that have committed minor infringements is also less then optimal. First, over-deterrence may lead to the prevention of not only illegal conduct but also actions that are socially desirable such as innovation. Excessive sanctions might therefore

43 Explanatory memorandum, supra note 12.

44 This somewhat follows the typology introduced by Wouter Wils in: 'The Use of Settlements in Public Antitrust Enforcement: Objectives and Principles' (2008) 31(3) World Competition 335-352.

45 E. Combe, 'À la recherché de la sanction optimale' (2006) 4 Concurrences 12. In that regard, an amount of a fine should ideally be multiplied by an inverse probability of detection. K.N. Hylton, Antitrust Law - Economic Theory and Common Law Evolution, Cambridge 2003, p. 49. 
have a chilling effect on competition ${ }^{46}$. Second, it is necessary to maintain 'marginal deterrence' whereby the level of punishment reflects the gravity of the offence ${ }^{47}$. If an equally harsh fine is imposed on a minor infringement and on a hard-core price fixing cartel for instance, then committing the latter is deterred far less effectively then committing the former. It seems therefore that commitment decisions are desirable in cases where no major harm was inflicted on society as a result of the scrutinised restriction ${ }^{48}$.

This interpretation is commensurate with Article 89 of the former Polish Competition Act applicable before the commitments procedure was introduced. On its basis, UOKiK could issue a decision banning further exercise of the contested practice without imposing a fine - that possibility was limited however to cases of minor violations only ${ }^{49}$. In case of most severe infringement adequate deterrence is more important than investigation costsavings, and ought to be sanctioned by a fine ${ }^{50}$. On the other hand, the cost of an intervention against minor infringements in an adversarial procedure is relatively high compared to associated societal gains, that is, the fine and the degree of compliance achieved. What really matters is to restore competition on a particular market as quickly as possible. Voluntary commitments seem to be an appropriate means of achieving such an objective.

The latter idea underpinned the introduction of the commitment procedure into Polish antitrust procedure ${ }^{51}$. Nevertheless, unlike Regulation 1/2003, the Competition Act does not preclude its application in cases where a fine could be imposed ${ }^{52}$. To the contrary, the fact that an undertaking can cease committing an anticompetitive practice without being fined for its exercise is noted as one of its advantages in the explanatory memorandum to the

46 P. Buccirossi, L. Ciari, T. Duso, G. Spagnolo, C. Vitale, 'Deterrence in Competition Law' GESY Discussion Paper No. 285, p. 7. See more specifically J.F.Brodley, 'Antitrust law and innovation cooperation' (1990) 4(3) Journal of Economic Perspectives 97-112.

47 G.J. Stigler, 'The Optimum Enforcement...', p. 527.

48 See generally I. Forrester, 'Creating New Rules? Or Closing Easy Cases? Policy Consequences for Public Enforcement of Settlements under Article 9 of Regulation 1/2003' [in:] C.-D. Ehlermann, M. Marquis (eds.), European Competition Law Annual 2008..., p. 637661. It is also commensurate with Article 89 of the former Competition Act which explicitly foresaw that only minor infringements could be dealt with by a decision prohibiting the exercise of a practice in place of a fine.

49 See subsection 2, above. As a result, it was not suitable to encompass horizontal agreements restricting competition. R. Molski, 'Programy lagodnego traktowania - panaceum na praktyki kartelowe?' (2004) 1 Kwartalnik Prawa Publicznego 217.

${ }^{50}$ Cf. W. Wils, 'Optimal Antitrust Fines...', p. 344.

51 Supra note 12 (Projekt ustawy...).

52 Cf. recital 13 of the Preamble to Regulation 1/2003. Although the enforcement practice of the Commission casts some doubt as to whether it effectively holds to this condition. 
amending act ${ }^{53}$. Literature confirms in this respect that Article 12 of the Competition Act allows the application of the commitments procedure to all kinds of competition restrictions, including hard-core violations ${ }^{54}$.

Such an approach might lead to under-deterrence if commitments were to be accepted in place of a fine - undertakings might not be sufficiently prevented from violating competition rules. It might also interfere with the fine immunity programme in cartel cases, since entrepreneurs can try to substitute leniency for commitment decisions and thus avoid stigmatization and the risk of followon claims. The solution to this problem seems to reside in the discretion to adopt commitment decisions that the legislator vested in the UOKiK President. Since grave competition law restrictions are not excluded from the Polish commitments procedure a priori, it will be up to the authority to decide which cases can be solved with the help of this enforcement tool ${ }^{55}$.

For instance, a commitment was accepted in the past where an undertaking active in the market for construction products has removed from its contracts a minimum resale price clause ${ }^{56}$, despite the fact that such practice amounts to a hard-core price fixing cartel ${ }^{57}$. However, the authority justified its decision by reference to the particular circumstances of the case. It was observed that the contested clause obliged retailers to refrain from the sale of the products in question below their wholesale price. Since it is economically unreasonable to offer products with a retail price inferior to their wholesale cost, the authority concluded that the anticompetitive effect of the said agreement was limited and could only concern promotional activities by retailers ${ }^{58}$. Moreover, the authority stressed that it is normally unwilling to accept commitments in cases of such grave violations suggesting therefore that the aforementioned case was to be seen as an exception rather than a rule to its enforcement practice ${ }^{59}$. It would be desirable for UOKiK to hold to that statement.

The Polish competition authority was so far consistent in its choices issuing commitments decisions in cases concerning restrictions of access to an essential facility ${ }^{60}$ or unfair contractual conditions ${ }^{61}$ where a rapid remedy was crucial.

53 Supra note 12 (Projekt ustawy...).

54 D. Miąsik, [in:] T. Skoczny, A. Jurkowska, D. Miąsik (eds.), Ustawa o ochronie konkurencji i konsumentów. Komentarz, Warszawa 2009, p. 740.

55 K. Kohutek, [in:] K. Kohutek, M. Sieradzka, Ustawa ..., p. 435.

56 Decision DOK-3/2008.

57 K. Kohutek, [in:] K. Kohutek, M. Sieradzka, Ustawa ..., p. 270.

58 Decision DOK-3/2008, at 24.

59 Ibid.

${ }^{60}$ Such as access to bus stops, Decisions of the UOKiK President of 26 November 2009, RGD-36/2009 and of 7 February 2008, RŁO-3/2008.

61 Decision No. 7/2009 (obliging waste-collecting firms to deliver it to a particular site), and Decisions of the UOKiK President of 16 March 2009, RKT-06/2009, of 11 June 2008, 
However, a more recent decision relating to an abuse of dominance on the market for television transmission of sporting events deviates slightly from this path. In that case, Polsat TV used the exclusive rights it obtained to transmit the Euro 2008 football championship to tie the sale of television decoders and a special maintenance service. As a result, many of its customers had to sign disadvantageous agreements to the benefit of Polsat. A fine seemed an appropriate measure to punish the firm. The UOKiK found however that it was sufficient for the broadcaster to commit itself cumulatively to refrain from including such conditions into future contracts, to buy back the contested decoders and to return the maintenance costs. It is likely that the authority's prime concern was here on restorative justice and thus it decided to accept commitments to restore the situation from before the infringement ${ }^{62}$. It will be interesting to see the future application practice of commitment decisions. However, similar cases should be treated by UOKiK with caution for reasons of optimal competition law enforcement.

\section{Improving legal certainty}

Over-enforcement can on the other hand also result from legal uncertainty. Firms may be reluctant to introduce new products or services (developed through costly R\&D) if they have doubts about the assessment of their practices by UOKiK. This is particularly relevant for new types of infringements, such as margin squeeze, and for the most sophisticated forms of antitrust violations. It is thus essential to clarify the law and establish under what conditions will particular market behaviour be regarded as anticompetitive ${ }^{63}$. This is even more true in the wake of the 'economization' of competition law both in the EU and Poland with its effects focus ${ }^{64}$. These would have to be clearly identified in order to clarify the content of the prohibition.

The use of commitment decisions by UOKiK should therefore not interfere with legal certainty that must be provided by competition law. Legal certainty can be assured best if, after having collected compelling evidence, the authority

RWR-24/2008, and of 28 August 2007, RWA-27/2007 (unfair contractual conditions imposed by dominant undertakings in water supply agreements).

62 See more on that in the section III.3 below.

63 W. Wils, 'Optimal Antitrust Fines...', p. 344.

${ }^{64}$ K. Kohutek, [in:] K. Kohutek, M. Sieradzka, Ustawa..., p. 71 et seq; $C f$. the judgment of the Polish Supreme Court of February 19, 2009, (III SK 31/08, Lex No. 503413), interpreted by literature as a manifestation of the more economic effect-based approach. See T. Skoczny, [in:] T. Skoczny, A. Jurkowska, D. Miąsik (eds.), Ustawa..., Warszawa 2009, p. 614; K. Kohutek, 'Zarzut nadużycia pozycji dominującej na rynku usług weterynaryjnych - glosa do wyroku Sądu Najwyższego z 19.02.2009 r. (III SK 31/08)' (2009) 4 Glosa 103. 
issues a formal decision establishing an infringement in cases of complex, novel and sophisticated violations. UOKiK findings are subsequently subject to judicial review contributing further to the clarification of the content of the prohibition ${ }^{65}$. The same result cannot be achieved by commitment decisions. Their lower standard of proof makes it impossible for courts to review them fully from the perspective of the alleged infringement and its effects on competition. The need for legal certainty in competition law supports thus an argument that the UOKiK President should enjoy wide discretion in accepting commitments allowing the authority to independently formulate its competition policy ${ }^{66}$.

It seems that UOKiK's use of the commitments procedure is commensurate with the requirements of legal certainty. The cases picked so far were not posing difficulties in relation to the establishment of an infringement and were not particularly novel. Moreover, the standard of proof in commitment decisions, even though limited, may give some indications as to the content of the prohibition embodied in the Polish Competition $\mathrm{Act}^{67}$. UOKiK goes even further in its concerns about legal certainty in adopting negotiated instruments by stating that:

'decisions issued by the President of the Office play a two-fold role. Firstly, they constitute a finding of a breach in a particular case, in relation to a given practice

65 The appellate court is entitled not only to annul a UOKiK decision but also to substitute it and rule on the matter at hand. M. Sieradzka, 'Sądowa weryfikacja decyzji i postanowień wydawanych przez Prezesa Urzędu Ochrony Konkurencji i Konsumentów' (2007) 10 Rejent 90-113.

66 See M. Stafaniuk, 'Decyzje wydawane w oparciu o zobowiązania składane przez przedsiębiorców jako przykład działań organów administracji w prawie antymonopolowym, opartych na idei zastosowania środków alternatywnego rozstrzygania sporów (Zarys Problematyki)' [in:] J. Olszewski (ed.), Arbitraż i mediacja: Praktyczne aspekty stosowania przepisów. Materiaty konferencyjne (Iwonicz Zdrój 18-20.10.2007 r.), Rzeszów 2007, p. 274. In that respect, the proposal of the Working Group of the Polish Competition Law Association, requiring the UOKiK President to respond to the commitments offered within 14 days does not seem to be an appropriate solution. It would, of course, improve the effectiveness of the procedure by putting pressure on the authority and thus incline it to accept commitments more often. However, it might also interfere with independent formulation of the competition policy since the rejection of commitments (which have to be reasoned) may constitute a ground for appeal. Stowarzyszenie Prawa Konkurencji, Stanowisko Grupy Roboczej Stowarzyszenia Prawa Konkurencji w sprawie propozycji zmian przepisów ustawy z dnia 16 lutego 2007 r. o ochronie konkurencji i konsumentów [Position of the Working Group of the Competition Law Association on the proposal for an amendment of the provisions of the Act on Competition and Consumer Protection of 16 February 2007], available at: http://www.spk.com.pl/funkcje/pobierz. php?plik=download $|2008-10-06|$ spk_postulaty_grupy_roboczej.pdf.

67 Since the infringement has to be rendered plausible, it tells which behaviour is likely to constitute a violation of competition law. There can be, however, no certainty about that. See section II.3 above. 
employed by particular undertaking, but simultaneously they are an important information for other market participants with respect to what potential comportment may be seen (or not) as a manifestation of an anticompetitive practice. The decisions of the President of the Office influence thus the process of attitude shaping of market participants, and by doing so fulfilling the public objective indicated by the act ${ }^{6} 68$.

The UOKiK President may have gone a little too far by attaching so much importance to commitment decisions. It is questionable whether market attitudes should in fact be shaped on the basis of negotiated instruments, which are subject to a limited degree of juridical review ${ }^{69}$. It has to be borne in mind here that despite the effort undertaken by UOKiK to demonstrate a high probability of an antitrust violation, a decision issued under Article 12 does not lead to the establishment of an infringement. The undertaking concerned merely commits not to adopt certain practice in the future, a fact which - contrary to the opinion of $\mathrm{UOKiK}^{70}$ - should not assure legal certainty for third parties. Furthermore, the UOKiK President admitted in the Polsat decision that 'the commitment in question should be regarded in a broader sense as an attempt to create positive market behaviours for the transmission of major sporting events' ${ }^{71}$. This reveals 'regulatory-like' ambitions on the part of the competition authority created by the opportunities inherent in the commitment procedure. Competition law may be used to support regulation on the market ${ }^{72}$; the UOKiK President should resist however the temptation to use commitments as a mean of market regulation ${ }^{73}$. Therefore, taking into account the individual and voluntary nature of commitment decisions. In any case, their role should not be exaggerated and go beyond mere information about the remedies adopted in a particular case in order to restore competition on a given market ${ }^{74}$.

68 Decision DOK-1/2010, at 39.

69 It would be difficult for the undertaking in question to contest the adequacy or proportionality of commitments which it proposed itself voluntarily. D. Miąsik, [in:] T. Skoczny, A. Jurkowska, D. Miąsik (eds.), Ustawa..., p. 751.

70 Ibid.

71 Ibid., p. 40.

72 See on that C. Banasiński, M. Krasnodębska-Tomkiel, 'Zastosowanie środków prawnych prawa antymonopolowego na szczególnych rynkach regulowanych' (2009) 1 Przegląd Prawa Handlowego 18-22.

73 This was reproached to the EU Commission, which accepted behavioural and structural remedies proposed in form of commitments on traditionally regulated market, such as gas and electricity. Klees A., 'Das Instrument der Zusageentscheidung und der Fall 'E.ON.' - Ein (weiterer) Sündenfall' (2009) 4 Wirtschaft und Wettbewerb 374-382. See also H. Schweitzer, 'Commitment Decisions under Article 9 of Regulation 1/2003: The Developing EC Practice and Case Law' (2008) 22 EUI Working Paper Law 11.

74 This conclusion is also supported by the resolution of the Supreme Court of 23 July 2008 (III CZP 52/08, (2009) 2 Monitor Prawny, item 90), where it held that 'decision foreseen in 


\section{Restorative justice}

Despite a commitment by an undertaking to stop an allegedly anticompetitive practice, its negative effects may persist on the market and impede competition. This is the case, for instance, where business partners are bound by obligations unduly imposed on them by a dominant firm ${ }^{75}$. These negative consequences affect mainly the customers of the offender and their removal is in the best interest of the victims. However, contrary to the finding of an infringement, a commitment decision does not affect contract validity, nor does it constitute a basis for follow-on claims. As a result, accepting commitments might hinder the pursuit of due rights by those harmed by the practice, since an infringement decision could not be invoked in a litigation before a civil court ${ }^{76}$. Should thus UOKiK take into account individual interests of third parties when contemplating the acceptance of commitments ${ }^{77}$ ? The authority has repeatedly stressed the public nature of Polish competition law which excludes the pursuit of individual interests through its enforcement ${ }^{78}$. Nonetheless, in one of its recent decisions the UOKiK President accepted, among others, a commitment to buy back products that were unlawfully tied to the principal service offered ${ }^{79}$. In another case, the authority required all agreements for water supply containing the contested clauses to be modified with an ex-tunc

Article 11a [now Article 12] of does not decide in a definitive on the violation of the prohibition inferred from Article 8 (1) [now Article 9 (1)] of the act, since it is based merely on rendering violation of that prohibition plausible'.

75 Such additional services and products tied to the sale of rights to display a sporting event (Decision DOK-1/2010), fees not reflecting effectively rendered services (Decision RKT$06 / 2009$ ) or liabilities towards a dominant undertakings tied to the sale of lumber (Decision RBG-12/2006).

76 A. Jurkowska-Gomułka, 'W stronę ....' and C. Banasiński, E. Piontek, Ustawa..., p. 314.

77 In several cases some NCAs and the European Commission took into account the fact that the effects of infringements were mitigated through compensating victims by undertakings responsible for a breach of competition rules. W. Wils, 'The Relation between Public Antitrust Enforcement and Private Actions for Damages' (2009) 32(1) World Competition 19-21.

78 See for instance judgment of the Supreme Court of 29 May 2001, I CKN 1217/98, where it held inter alia that the objective of the Competition Act is not to protect an individual player on the market, who can avail itself of claims available before a civil court. This situation is contrary to the private enforcement of competition law, which presumes 'enforcement of competition law for the sake of competition and not merely for the sake of one's own interests', W. van Gerven, 'Crehan and the Way Ahead' (2006) 17(2) European Business Law Review, at 269. On the protection of public and private interest under Polish competition law see also P. Podrecki, Porozumienia monopolistyczne i ich cywilnoprawne skutki, Kraków 2000, p. 221 et seq., and D. Miąsik, 'Controlled Chaos with Consumer Welfare as the Winner - a Study of the Goals of Polish Antitrust Law' (2008) 1(1) YARS 33-58.

79 Decision DOK-1/2010. 
effect $^{80}$. Still, in other decisions, a commitment not to continue a tying practice was found to be satisfactory despite the fact that the liabilities tied to sale of products, bearing no market value, were not assigned back to the dominant undertaking ${ }^{81}$. Overall, the competition authority should not be overly concerned with corrective justice. The resulting benefits for the victims of an infringement, such as returning the price of unduly tied service, constitute an indirect consequence of an effort to restore effective competition ${ }^{82}$.

In the absence of a formal infringement decision in an adversarial procedure, civil courts are still empowered to establish a violation of competition law and draw from that fact any necessary consequences ${ }^{83}$. Moreover, the commitments procedure does not require proof of an infringement taking place but merely the probability of its existence. This should generally exclude the possibility of requiring the company subject to a commitment decision to compensate its alleged victims or to hand over the benefits arising from a void contract. However, such a proposal may indeed increase the chances of an offender to have its commitments accepted and avoid a fine ${ }^{84}$.

When proposing commitments, an undertaking should thus be primarily concerned with the situation on the affected markets. Its offer should focus on eliminating the remains of the questionable practice. Private interests of individuals affected by the comportment should be left out of the scope of the commitment procedure. In a case where considerable harm has been inflicted to numerous entities, the authority should contemplate an infringement decision in order to discourage the offender, as well as others, from adopting similar practices. The official establishment of an infringement would open the way for private follow-on actions based on that decision, which would be binding on civil courts.

80 Decision RKT-06/2009.

81 Decision RBG-12/2006.

82 This follows from a recent decision of the UOKiK President accepting a commitment to reduce termination period of agreements for copyrights management by ZAiKS (Authors' Association). The President considered proposed measure to be appropriate to alleviate the deficiency of competition on the market for managing of copyrights. Decision DOK-7/2010.

83 Resolution of the Supreme Court, see supra note 74. More specifically on the civil law remedies following a decision of the President of the UOKiK see R. Poździk, 'Glosa do uchwały SN - Izba Cywilna - z dnia 23 lipca 2008 r. (III CZP 52/08)' (2009) 7-8 OSP 605 et seq. and E. Rumak, P. Sitarek, 'Polish Leniency Programme and its Intersection with Private Enforcement of Competition Law' (2009) 2(2) YARS 115.

${ }^{84}$ Decision DOK-1/2010. It should be assessed in the lights of other objectives referred to in this paper, whether that would be a desirable solution from the viewpoint of optimal antitrust enforcement. 


\section{Conclusion}

The introduction of a commitments procedure into Polish antitrust law responded to the needs of economic reality. Familiar concepts of national competition law were incorporated into the framework of the European Competition Network. It is remarkable though that the legislator gave such a considerable degree of discretion to the competition authority in determining the conditions of its practical use. In that respect, 'effectiveness' is the only explicit criterion for adopting a commitment decision by the UOKiK President ${ }^{85}$.

However, other above-mentioned factors that follow from the general goals of the Competition Act, as defined in its Article 1, should also be taken into account. Compliance with these aims can be taken into account in the course of appeal proceedings before the court competent in competition matters. In that regard, it is formally feasible for the appellate court to substitute commitments for an infringement decision ${ }^{86}$, even though the practical possibility of such ruling is limited ${ }^{87}$. Therefore, it is essential for the UOKiK President to apply the commitments procedure in accordance with these goals rather than focus exclusively on procedural efficiency ${ }^{88}$. So far, UOKiK's enforcement practice confirmed that the Polish competition authority understands well the role of commitments. By applying this instrument to minor infringements, the enforcement of domestic competition law benefited from costsavings (mainly by avoiding appeal proceedings) without prejudice to the deterrence of potential violations ${ }^{89}$. Moreover, the study of UOKiK decisions shows that the authority uses commitments mainly in cases where they can restore competition more effectively than an infringement decision. It is also aware of the clarifying role of antitrust enforcement. Nevertheless, it should not overestimate the content of commitments decisions as they cannot serve as a benchmark for third party self-assessment. Otherwise, they would have to

85 This follows from the preparatory acts, where improving effectiveness of the antitrust proceeding was main concern. See supra note 12 (Projekt ustawy...).

${ }^{86}$ M. Sieradzka, 'Sądowa weryfikacja...', p. 106.

87 Firstly, an infringement decision require a proof of violation of competition law and not merely rendering this fact plausible, and - secondly - becuase of prohibition of reformatio in peius. D. Miąsik, [in:] T. Skoczny, A. Jurkowska, D. Miąsik (eds.), Ustawa ..., p. 751.

${ }^{88}$ Generally on the risk accompanying introducing more efficient procedural solutions into the EU antitrust law R. Whish, 'Commitment Decisions under Article 9 of the EC Modernisation Regulation: some unanswered questions' [in:] M. Johansson, N. Wahl, U. Bernitz (eds.), Liber Amicorum in honour of Sven Norberg. A European for all Seasons, Bruxelles 2006, p. 564 et seq.; G.S. Georgiev, 'Contagious Efficiency: The Growing Reliance on U.S.-Style Settlements in EU Law' (2007) 4 Utah Law Review 971-1031.

89 This is clearly demonstrated by accepting commitments in the price-fixing cartel case, what the UOKiK President justified with little harm inflicted to the society. 
stand up to a much higher standard of proof decreasing in turn the efficiency of the commitments procedure.

What is striking though is the low number of commitment decisions issued by the UOKiK President in the six years since the procedure was introduced. Certainly, the authority was initially cautious in using the new instrument in order to correctly develop its application practice. Commitments were indeed contemplated in numerous cases. However, where the existence of an infringement was clear and the acceptance of commitments would not have facilitated major benefits for the market (e.g. immediate restoration of the competition), the authority issued infringement decisions instead. Although, its reluctance to accept commitments is criticized by the industry ${ }^{90}$, it is essential to make it possible for the authority to use its full discretion in accepting commitments and thus to independently formulate its competition policy ${ }^{91}$. It is also possible that the UOKiK President wants to avoid any adverse effect of the commitment procedure on the leniency programme, making sure that the latter is not substituted by the former. The application practice of the Polish commitments procedure does not seem to be fully established yet but its past success should catalyse its developments in the years to come.

\section{Literature}

Adelstein R., Miceli T.J., 'Toward a Comparative Economics of Plea Bargaining' (2001) 11(1) European Journal of Law and Economics.

Banasiński C., Piontek E. (eds.), Ustawa o ochronie konkurencji i konsumentów. Komentarz [Act on Competition and Consumer Protection. Commentary], Warszawa 2009.

Besanko D., Spulber D.F., 'Antitrust Enforcement under Asymmetric Information' (1989) 99 The Economic Journal.

90 In order to incline the UOKiK to accept commitments more regularly the Working Group of the Polish Competition Law Association tabled a proposal, requiring the President of the UOKiK to respond to the proposal of commitments within 14 days. Stowarzyszenie Prawa Konkurencji, Stanowisko Grupy Roboczej Stowarzyszenia Prawa Konkurencji w sprawie propozycji zmian przepisów ustawy z dnia 16 lutego 2007 r. o ochronie konkurencji i konsumentów [Position of the Working Group of the Competition Law Association on the proposal for amendment of provisions of the Act on Competition and Consumer Protection of 16 February 2007], available at: http://www.spk.com.pl/funkcje/pobierz.php?plik=download|200810-06|spk_postulaty_grupy_roboczej.pdf.

91 Imposing on the UOKiK an obligation to respond to a proposal of commitments, might be used as a ground to challenge decision if such obligation was not observed, what would impede the effectiveness of the procedure and thus should generally be inadmissible. D. Miąsik, [in:] T. Skoczny, A. Jurkowska, D. Miąsik (eds.), Ustawa ..., p. 751. 
Bogomilska-Król M., 'Kary pieniężne - główne kierunki ewolucji w okresie 20 lat rozwoju polskiego prawa antymonopolowego' ['Pecuniary penalties - main directions of evolution during the 20 years of development of Polish antimonopoly law'] (2010) 5 Europejski Przeglad Sąowy.

Brodley J.F., 'Antitrust law and Innovation Cooperation' (1990) 4(3) Journal of Economic Perspectives.

Buccirossi P., Ciari L., Duso T., Spagnolo G., Vitale C., 'Deterrence in Competition Law' GESY Discussion Paper No. 285.

Banasiński C., Krasnodębska-Tomkiel M., 'Zastosowanie środków prawnych prawa antymonopolowego na szczególnych rynkach regulowanych' ['Application of antimonopoly law remedies in particular regulated markets'] (2009) 1 Przeglad Prawa Handlowego.

Combe E., 'À la recherché de la sanction optimale' (2006) 4 Concurrences.

Forrester I., 'Creating New Rules? Or Closing Easy Cases? Policy Consequences for Public Enforcement of Settlements under Article 9 of Regulation 1/2003' [in:] Ehlermann C.D., Marquis M. (eds.), European Competition Law Annual 2008: Antitrust Settlements and EC Competition Law, Oxford 2010.

Georgiev G.S., 'Contagious Efficiency: The Growing Reliance on U.S.-Style Settlements in EU Law' (2007) 4 Utah Law Review.

Gill A., Swora M., 'Decyzja zobowiązująca jako metoda rozwiązywania sporów w postępowaniu przed Prezesem Urzędu Ochrony Konkurencji i Konsumentów' ['Commitment decision as a mean of resolution of disputes before the President of the Office of Competition and Consumer Protection'] (2005) 3 Kwartalnik Prawa Publicznego.

Grossman G.M., Katz M.L., 'Plea Bargaining and Social Welfare' (1983) 73 The American Economic Review.

Hylton K.N., Antitrust Law - Economic Theory and Common Law Evolution, Cambridge, 2003.

Jurkowska-Gomułka A., 'W stronę umocnienia prywatnoprawnego wdrażania zakazów praktyk ograniczających konkurencję - glosa do uchwały SN z 23.0.2008 r. (III CZP 52/08)' ['Towards strengthening private enforcement of prohibitions of competitionrestraining practices - commentary on the Supreme Court resolution of 23 July 2008 (III CZP 52/08'] (2010) 5 Europejski Przeglad Sądowy.

Klees A., ,Das Instrument der Zusageentscheidung und der Fall 'E.ON.' - Ein (weiterer) Sündenfall' (2009) 4 Wirtschaft und Wettbewerb.

Kmieciak Z., Mediacja i koncyliacja w prawie administracyjnym [Mediation and Conciliation in the administrative law], Kraków 2004.

Kohutek K., Sieradzka M., Ustawa o ochronie konkurencji i konsumentów. Komentarz [Act on Competition and Consumer Protection. Commentary], Warszawa 2008.

Łaszczyca G., Martysz G., Matan A., Postępowanie administracyjne ogólne [General administrative procedure], Warszawa 2003.

Miąsik D., 'Controlled Chaos with Consumer Welfare as the Winner - a Study of the Goals of Polish Antitrust Law' (2008) 1(1) YARS.

Modzelewska-Wąchal E., Ustawa o ochronie konkurencji i konsumentów. Komentarz [Act on Competition and Consumer Protection. Commentary], Warszawa 2002.

Molski R., 'Programy lagodnego traktowania - panaceum na praktyki kartelowe?' ['Leniency programme - a panacea for cartel practices?'] (2004) 1 Kwartalnik Prawa Publicznego. 
Podrecki P., Porozumienia monopolistyczne i ich cywilnoprawne skutki [Monopolistic agreements and their consequences in private law], Kraków 2000.

Poździk R., 'Glosa do uchwały SN - Izba Cywilna - z dnia 23 lipca 2008 r. (III CZP 52/08)' ['Comment on the Supreme Court resolution - Civil Chambers - of 23 July 2008 (III CZP 52/08)’], (2009) 7-8 Orzecznictwo Sąów Polskich.

Rumak E., Sitarek P., 'Polish Leniency Programme and its Intersection with Private Enforcement of Competition Law' (2009) 2(2) YARS.

Schweitzer H., 'Commitment Decisions under Article 9 of Regulation 1/2003: The Developing EC Practice and Case Law' (2008) 22 EUI Working Paper Law.

Segal I.R., Whinston M.D., 'Public vs. Private Enforcement of Antitrust Rules: A Survey' Stanford Law School Working Paper No. 335.

Sieradzka M., 'Sądowa weryfikacja decyzji i postanowień wydawanych przez Prezesa Urzędu Ochrony Konkurencji i Konsumentów' ['Judicial verification of the decisions and resolutions issued by the President of the Office of Competition and Consumer Protection'] (2007) 10 Rejent.

Skoczny T., Jurkowska A., Miąsik D. (eds.), Ustawa o ochronie konkurencji i konsumentów. Komentarz [Act on Competition and Consumer Protection. Commentary], Warszawa 2009.

Spagnolo G., 'Leniency and Whistleblowers in Antitrust' [in:] Buccirossi P. (ed.), Handbook of antitrust economics, Cambridge 2008.

Stefaniuk M., 'Decyzje wydawane w oparciu o zobowiązania sładane przez przedsiębiorców jako przykład działań organów administracji w prawie antymonopolowym, opartych na idei zastosowania środków alternatywnego rozstrzygania sporów (zarys problematyki)' ['Decisions issued on a basis of commitments proposed by entrepreneurs as an example of actions of public authorities in antimonopoly law, based on the concept of application of alternative dispute resolutions measures'] [in:] Olszewski J. (ed.), Arbitraż i mediacja: praktyczne aspekty stosowania przepisów. Materiały konferencyjne (Iwonicz Zdrój 18-20.10.2007 r.) [Arbitration and mediation: practical aspect of application of provisions], Rzeszów 2007.

Stigler G.J., 'The Optimum Enforcement of Laws' (1970) 78(3) Journal of Political Economy.

Szpor A., 'Mediacja w prawie konkurencji. Prezes UOKiK jako mediator publiczny w sprawach praktyk ograniczających konkurencję' ['Mediation in competition law. President of the UOKiK as public mediator w cases of practices restricting competition'] [in:] Michnińska H., Mediacja w sprawach administracyjnych [Mediation in administrative matters], Warszawa 2007.

van Gerven W., 'Crehan and the Way Ahead' (2006) 17(2) European Business Law Review.

Whish R., 'Commitment Decisions under Article 9 of the EC Modernisation Regulation: some unanswered questions' [in:] Johansson M., Wahl N., Bernitz U., (eds.), Liber Amicorum in honour of Sven Norberg. A European for all Seasons, Bruxelles 2006.

Wilks S., 'A Political Science Approach: Restorative justice and the fairness critique' [in:] Ehlermann C.-D., Marquis M. (eds.), European Competition Law Annual 2008: Antitrust Settlements and EC Competition Law, Oxford 2010.

Wils W., 'Optimal Antitrust Fines: Theory and Practice' (2006) 29(2) World Competition.

Wils W., 'The Relation between Public Antitrust Enforcement and Private Actions for Damages' (2009) 32(1) World Competition.

Wils W., 'The Use of Settlements in Public Antitrust Enforcement: Objectives and Principles' (2008) 31(3) World Competition. 